\title{
Kolekcja argentyńska w Bibliotece Poznańskiego Towarzystwa Przyjaciół Nauk
}

Streszczenie. Przed 20 laty (w 1989 roku) Biblioteka Poznańskiego Towarzystwa Przyjaciół Nauk otrzymała w darze od polskiego emigranta z Argentyny Stanisława Lis-Kozłowskiego (1907-1995) kolekcję złożoną z poloników argentyńskich, materiałów źródłowych związanych z działalnością Polonii argentyńskiej, książek argentyńskich i Argentyny dotyczących oraz dzieł z historii Ameryki Łacińskiej. Darczyńca gromadził tę kolekcję ponad 40 lat - od 1948 roku, gdy wyemigrował do Argentyny.

Stanisław Lis-Kozłowski był inżynierem chemikiem i wybitnie zasłużonym wojskowym, oficerem Armii Krajowej (odznaczony najwyższymi odznaczeniami polskimi, brytyjskimi i francuskimi: 24 ordery, 16 odznaczeń), był ministrem pełnomocnym Rządu Polskiego na Wychodźstwie (w Paragwaju w latach 1974-1980), działaczem stowarzyszeń polonijnych, popularyzatorem polskiej kultury, nauki i historii (ponad 200 pozycji bibliograficznych), heraldykiem, słowianofilem, członkiem wielu międzynarodowych organizacji historycznych, kulturalnych i heraldycznych.

W artykule omówiono ciekawsze dzieła z czterech grup materiałów tej różnorodnej kolekcji.

Wśród poloników wyróżnia się grupa 28 tytułów czasopism emigracyjnych (w tym 3 tytuły w miarę kompletne: „Głos Polski”, „Nasza Sprawa” i Kurier Polski”), ponad 100 książek wydanych w Argentynie po polsku lub hiszpańsku (literatura polska, biografie Polaków, rozprawy historyczne, publicystyka polityczno-społeczna), wycinki z prasy argentyńskiej dotyczące Polski z lat 1955-1991.

Kolekcja jest dostępna na miejscu w czytelni, stan zachowania w przewadze dobry, część dzieł ma opisy w katalogu komputerowym Biblioteki (od odszukania przez indeks sygnatur od sygnatury 150.000 z literą ,"L" na końcu), część dzieł w katalogu kartkowym (alfabetycznym i systematycznym), a pozostałe wpisane są do inwentarza.

SŁowA KLuczowe: polonika argentyńskie, Polonia w Argentynie, Stanisław Lis-Kozłowski, Władysław Mieczysław Kozłowski. 
Przed 20 laty Biblioteka Poznańskiego Towarzystwa Przyjaciół Nauk otrzymała w darze od polskiego emigranta z Argentyny - Stanisława Lis-Kozłowskiego - kolekcję złożoną z poloników argentyńskich, materiałów związanych z życiem polskiej emigracji w Argentynie, wydawnictw argentyńskich lub dotyczących Argentyny oraz dzieł z historii Ameryki Łacińskiej. Z przekazaniem tego zbioru do Biblioteki w latach 80., a więc w czasach nadzorowania życia publicznego przez cenzurę, wiązało się prawie dziewięć lat zabiegów. Ofiarodawca złożył propozycję przekazania daru w listopadzie 1980 roku, ale zbiór trafił do Biblioteki dopiero w czerwcu 1989 roku. Po wielu perturbacjach sześć nienaruszonych skrzyń trafiło do portu w Gdańsku. Stamtąd zostały przewiezione do gmachu Ministerstwa Spraw Zagranicznych w Warszawie, skąd wreszcie - okazyjnym transportem - do Poznańskiego Towarzystwa Przyjaciół Nauk. Takie były losy kolekcji zza oceanu, którą przez ponad 40 lat darczyńca gromadził z myślą o starym kraju.

Oferta Lis-Kozłowskiego składała się z dwóch części: pierwsza dotyczyła przekazania w darze Bibliotece PTPN księgozbioru liczącego około 1400 woluminów o profilu filozoficznym, po ojcu - filozofie, Władysławie Mieczysławie Kozłowskim, zmarłym w 1935 roku profesorze Uniwersytetu Poznańskiego i członku PTPN (dar trafił do PTPN dopiero w 1996 roku). Druga część dotyczyła ofiarowania wyżej wspomnianej kolekcji poloników argentyńskich i wydawnictw związanych z Argentyną.

Obie kolekcje przechowywane są w osobnym gabinecie imienia ofiarodawcy na terenie Biblioteki PTPN. Opracowana część kolekcji jest udostępniana w czytelni.

To właśnie tę drugą część daru polecam uwadze hispanistów, historyków, badaczy związków kulturalnych między Polską a Argentyną oraz badaczy dziejów polskiej emigracji.

\section{Ofiarodawca}

Stanisław Lis-Kozłowski (ur. 22 lutego 1907 roku w Warszawie, zm. 28 czerwca 1995 roku Buenos Aires; urnę z jego prochami złożono w kaplicy rodu Lisów w kościele cystersów w Jędrzejowie) był inżynierem chemikiem i wybitnie zasłużonym wojskowym (uczestnik kampanii wrześniowej, walczył w konspiracji i w powstaniu warszawskim, oficer Armii Krajowej). Za akty odwagi w czasie II wojny światowej odznaczony został wieloma wysokimi odznaczeniami polskimi, brytyjskimi i francuskimi (24 ordery i 16 odznaczeń). Od kwietnia 1945 roku do momentu demobilizacji w 1948 roku służył w Polskich Siłach Zbrojnych na Zachodzie. 
W 1948 roku wyemigrował do Argentyny, gdzie początkowo znalazł zatrudnienie $w$ argentyńskim przemyśle chemicznym, a później utworzył własne przedsiębiorstwo. Jednocześnie przez 47 lat działał w polskich stowarzyszeniach emigracyjnych, a także jako współzałożyciel i współpracownik polskich czasopism emigracyjnych. Popularyzował kulturę, naukę i historię polską nie tylko w Argentynie, ale i w innych krajach Ameryki Południowej (ponad 200 pozycji bibliograficznych). Był także dyplomatą: w Paragwaju w latach 1974-1980 sprawował funkcję ministra pełnomocnego Rządu Polskiego na Wychodźstwie. Z zamiłowania heraldyk i słowianofil (idea federacji Słowian) - posiadał członkostwo wielu międzynarodowych organizacji historycznych, kulturalnych i heraldycznych. Zajmował się także hodowlą koni sportowych (hipika i polo).

Stanisław Lis-Kozłowski był synem filozofa Władysława Mieczysława Kozłowskiego (1858-1935), prekursora pragmatyzmu i twórcy tzw. humanizmu polskiego. Księgozbiór po tym uczonym (różnojęzyczne książki, czasopisma i rękopisy), za sprawą syna Stanisława, trafił także do Biblioteki PTPN. Stanisław Lis-Kozłowski założył dwie fundacje, z których jedna - Fundacja Lisów-Kozłowskich „Instytut Myśl i Życie im. Władysława Mieczysława Kozłowskiego" - miała na celu między innymi szerzenie idei głoszonych przez jego ojca (przestała działać w 2006 roku). Poza tym Stanisław Lis-Kozłowski opracował Materiały do bibliografii poloników argentyńskich 1898-1982, które zostały wydane (w 1996 roku, już po jego śmierci) wspólnie przez Bibliotekę Narodową i wspomnianą Fundację. Dzieło to zawiera bibliografię jego prac - ponad 200 pozycji bibliograficznych.

\section{Rodzaj kolekcji, jej wielkość, stan zachowania i opracowania}

Kolekcja składa się z czterech grup materiałów. Są to: polonika argentyńskie, polonika nieargentyńskie, dzieła wydane w Argentynie i poza nią w języku hiszpańskim i w innych językach, a dotyczące Argentyny, oraz niewielka liczba dzieł polskich. Poniżej krótka charakterystyka tych materiałów.

1. Zbiór poloników argentyńskich jest zróżnicowany formalnie. Zawiera dzieła zwarte i czasopisma, wycinki z prasy argentyńskiej dotyczące Polski, materiały polskich organizacji emigracyjnych działających w Argentynie, a także spis pozycji bibliograficznych Stanisława Lis-Kozłowskiego. Jest to rzeczywiście interesujący dokument życia Polonii i warto przyjrzeć się tym materiałom bliżej. 
a. Dzieła zwarte. Ta część kolekcji zawiera literaturę polską biografie Polaków, rozprawy historyczne i publicystykę polityczno-społeczna, wydawaną w Argentynie po polsku i po hiszpańsku. Jest to około 200 dzieł zwartych, w tym 110 dzieł skatalogowanych w katalogu kartkowym. Ze zbiorów można korzystać w czytelni. Stan zachowania różny, w przewadze dobry.

Wśród wartych odnotowania dzieł literackich w języku hiszpańskim są trzy książki Witolda Gombrowicza: El casamiento (Ślub) z 1948 roku, Ferdydurke z 1964 roku i Diario argentino (Dziennik) wydany w 1968 roku, broszura Romana Dmowskiego, La iglesia, la nacion y el estado (Kościót, naród i państwo), wydana w 1964 roku, książka Kazimierza Brandysa Ciudadanos (Obywatele) z 1958 roku, kilka wydań Chłopów Władysława Reymonta, a spośród dzieł Henryka Sienkiewicza Rodzina Połanieckich z 1917 roku, cztery wydania Quo vadis (w tym jedna wersja dla dzieci), Krzyżacy i Opowiadania. W kolekcji są także, wydane po hiszpańsku, dzieła: Stanisława Przybyszewskiego, Michała Choromańskiego, Josepha Conrada, Zofii Kossak, Jarosława Iwaszkiewicza, Janusza Korczaka, Ksawerego Pruszyńskiego. Jest nawet dzieło Mikołaja Kopernika O obrotach sfer niebieskich. Księga pierwsza - wydane w 1965 roku przez Uniwersytet w Buenos Aires.

Bardzo wartościowe dzieła historyczno-biograficzne to dwie książki Stanisława Pyzika o dziejach Polaków w Argentynie i Ameryce Południowej: Los Polacos en la Republica Argentina 1812-1900 algunos antecendentes historicos y biograficos z 1944 roku oraz Los Polacos en la Republica Argentina y America del Sur desdeano 1812: algunos antecendentes historicos y biograficos z 1966 roku. Interesujące są także trzy inne pozycje: wydana w 1945 roku historia Polski, tłumaczona na hiszpański z języka angielskiego - autorstwa Oskara Haleckiego Historia de Polonia, następnie niewielka książeczka o kulturze duchowej Żydów polskich - Heszela Klepfisza La cultura espirítual del judaísmo polaco i opublikowana w 1912 roku Polonia y Paraguay Carlosa A. Carranzy. W kolekcji tej są także biografie słynnych Polaków napisane przez autorów hiszpańskich. Aż trzech różnych autorów w latach 1943-1946 zajęło się postacią Fryderyka Chopina, a w latach 50. jeden z nich ponownie pisał o naszym sławnym muzyku (Chopin o el poeta); są też teksty o Marii Skłodowskiej-Curie, Mikołaju Koperniku, Ludwiku Zamenhofie i papieżu Janie Pawle II. Z publicystyki politycznej warto odnotować książkę Zbigniewa Brzezińskiego La purga permanente: realidad de la politica en el Soviet z 1958 roku, której ty tuł w tłumaczeniu polskim brzmi "Czystka permanentna: prawda o polityce w Sowietach", oraz zbiór dokumentów rządu polskiego na wygnaniu z 1940 roku Las relaciones polacogermanas y polacosovieticas el periodo 1933-1939: collecion de documentos oficiales Republica Polonia-Ministerio de Relaciones Exteriores. 
Z literatury $\mathrm{w}$ języku polskim zainteresować może proza wydawana w latach 30. XX wieku: Kazimierza Seysse-Tobiczyka Monte Adamello. Opowiadania z podobłocznych wyżyn z 1937 roku, Zygmunta Robaka Dziwy brazylijskie. Nowele z 1937 roku i tegoż autora List z puszczy z 1939 roku oraz Jerzego Pomiana Orzet $i$ Tartan z 1939 roku. W tej części kolekcji są też książki w języku polskim z lat 40.: Kazimierza Wierzyńskiego Ziemia wilczyca (wiersze) z 1941 roku, trzytomowa powieść Floriana Czarnyszewicza Nadberezyńcy z 1942 roku, Wacława Śledzińskiego Swastyka nad Warszawa. Dwa i pót roku pod okupacja niemiecka w Polsce z 1945 roku oraz trzy książki publicystyczne o politycznych aspektach toczącej się wówczas II wojny światowej (lub wydane tuż po jej zakończeniu): Witolda Ipohorskiego-Lenkiewicza Minister z pałacu Brühla. U źródeł drugiej wojny światowej z 1943 roku, tegoż autora Lilie cmentarne. Polska i Rosja z 1944 roku oraz Granice Polski z roku 1946. Do ważnych pozycji należą Materiały do bibliografii polonica Ameryki Łacińskiej Alberta Bukieta, wydane w Buenos Aires w 1975 roku, oraz teksty o charakterze praktycznym: Polsko-hiszpański słownik-przewodnik = Diccionario-guia: zawiera informacje o Argentynie autorstwa S.A. Smyczyńskiego i S. Kalinowskiego z 1947 roku, Prawa i obowiazki pracowników w Argentynie Zdzisława Gałczyńskiego z roku 1948, Ochrona pracy w Argentynie Romana Ciechanowa z 1949 roku i polsko-hiszpańskie kompendium zawierające reklamy firm polonijnych Informator społeczno-gospodarczy Polonii w Argentynie z roku 1977. Do dokumentów życia Polonii zalicza się: Piętnaście lat pracy Klubu Polskiego w Buenos Aires 12.11.1940-12.11.1955 oraz Nasza Sprawa: 1930-63 (jednodniówka z okazji jubileuszu 35-lecia Stowarzyszenia Polskich Kombatantów w Argentynie). Jako ciekawostkę warto odnotować wydany w Buenos Aires w 1928 roku Samouczek polsko-hiszpański wraz ze słownikiem polsko-hiszpańskim, który zapewne mocno się przysłużył rzeszom polskich emigrantów.

b. Zbiór czasopism. Biblioteka wzbogaciła się o 28 tytułów. Są one skatalogowane alfabetycznie w katalogu komputerowym, a także rzeczowo (w katalogu kartkowym) w dziale katalogu systematycznego: czasopisma polonijne. Są to głównie pojedyncze numery czasopism. Wyjątkiem są trzy, w miarę kompletne, tytuły w języku polskim, ukazujące się w Buenos Aires: tygodnik „Głos Polski: La Voz de Polonia” za lata 1950-1991, organ Związku Polaków w Argentynie, „Nasza Sprawa: biuletyn informacyjny Polskiego Związku b[yłych] Wojskowych i Obrońców Ojczyzny w Argentynie" za lata 1952-1957 i jego kontynuacja za lata 1957-1976 - tygodnik „Kurier Polski = Correo Polaco: tygodnik niezależny na Amerykę Południową" wydawany przez Polską Spółkę Wydawniczą - Editorial Polaca SRL, oraz miesięcznik „Bóg i Ojczyzna: organ Koła Katolików-Polaków 
w Buenos Aires" wydawany w latach 1950-1973 (roczniki niekompletne). Z czasopism można korzystać w czytelni; stan zachowania w większości dobry.

c. Wycinki z prasy argentyńskiej dotyczące Polski z lat 1955-1991 $2 \mathrm{~m}$ bieżące. Wycinkom nadano już sygnatury i ułożono je $\mathrm{w}$ teczki, $\mathrm{z}$ zachowaniem chronologii (każdy rok osobno, a w ramach roku podział na miesiące). Jedynym wyjątkiem jest wydzielona przez ofiarodawcę teczka monograficzna dotycząca Poznańskiego Czerwca 1956 i pierwszej rocznicy czerwcowych wydarzeń. Wycinki w przyszłości zostaną opracowane rzeczowo i otrzymają indeks przedmiotowy: osób i miejscowości. Stan zachowania w przewadze dobry. Wycinki mogą być udostępnione w czytelni.

d. Materiały polskich organizacji emigracyjnych działających w Argentynie (związków i stowarzyszeń) - około 25 tek. Są bardzo różnorodne: fotografie, okazjonalne broszury, związane z imprezami okolicznościowymi, kilka czasopism do użytku wewnętrznego, sprawozdania z posiedzeń stowarzyszeń, rękopisy z notatkami, bruliony scenopisów sztuk wystawianych na scenach amatorskich itp. Stan zachowania w przewadze dobry. Zostaną opracowane zgodnie z zasadami opracowania zbiorów rękopiśmiennych. W chwili obecnej są jedynie wstępnie posegregowane rzeczowo. Mogą być udostępnione w czytelni.

e. Spis pozycji bibliograficznych Stanisława Lis-Kozłowskiego (ponad 200 pozycji bibliograficznych, głównie artykuły w prasie polonijnej i argentyńskiej). Spis prac drukowany był w opracowanej przez Stanisława Lis-Kozłowskiego książce Materiały do bibliografii poloników argentyńskich 1898-1982 (sygnatura Biblioteki PTPN 3000285 PB III 8/56).

2. Zbiór poloników nieargentyńskich. Wśród ciekawszych dzieł zwartych wymienić można: urugwajskie, popularyzujące kulturę polską, pięć druków z lat 1939-1945, wydanych w Montevideo, trzy kanadyjskie - w tym ważne dzieło The polish past in Canada: contributions to the history of the Poles in Canada and of the polish-canadian relations wydane w Toronto w 1960 roku oraz będące kontynuacją bibliografii Wiktora Turka Polonica canadiana. Poza tym jeden druk brazylijski - raczej ciekawostka - licząca 77 stron powieść Henryka Sienkiewicza w języku polskim - wydanie dla dzieci W pustyni i puszczy: w obrazkach (Curitiba 1955). Interesującym nabytkiem dla Biblioteki okazały się czasopisma polskie, uzupełniające już posiadane roczniki - wydane w Paryżu: „Kultura” i „Zeszyty Historyczne” (kilkadziesiąt roczników), wydane w Londynie: „Wiadomości” i "Orzeł Biały” (w sumie kilkanaście roczników) oraz kilka innych periodyków (w przewadze pojedyncze numery). Część poloników nieargentyńskich wpisana została do katalogu Biblioteki i może być udostępniona w czytelni. Stan zachowania w przewadze dobry. 
3. Dzieła wydane w Argentynie i poza nią w języku hiszpańskim i w innych językach, a dotyczące Argentyny. Są to dzieła zwarte i wydawnictwa seryjne - około $15 \mathrm{~m}$ bieżących, $\mathrm{z}$ tego około 300 woluminów wpisanych do inwentarza Biblioteki (można przejrzeć w czytelni). Są częściowo skatalogowane w katalogu komputerowym. Między innymi: Biblioteca de Mayo: colleción de obras y documentos para la historia argentina. Memorias, autobiografias, diarios y cronicas. Buenos Aires 1960-196320 woluminów, sygnatura 150142L; Historia Wenezueli - 50 woluminów, ale z lukami, sygnatura 150143L; Historia świata współczesnego - 25 woluminów, sygnatura 150154L; Archiwum generała Mirandy [Archivo del general Miranda] - 22 tomy zawierające dokumenty z lat 1750-1812, wydawane w latach 1929-1950 w Hawanie i Caracas, sygnatura 150145L; źródła do historii prowincji Buenos Aires w Argentynie, sygnatura 150184L. Dostępne w czytelni.

4. Dzieła polskie - około 30 dzieł zwartych i kilka tytułów czasopism (niekompletnych) - wydawnictwa XX-wieczne. Wpisane jedynie do inwentarza, niedostępne w katalogach Biblioteki, z wyjątkiem dwóch dzieł traktujących o Argentynie i Ameryce Łacińskiej, które są uwidocznione w katalogu kartkowym: Józefa Włodka Argentyna i emigracja: ze szczególnym uwzględnieniem emigracji polskiej wydana w Warszawie w 1923 roku oraz Dzieje Polonii w Ameryce Łacińskiej: zbiór studiów wydane w Warszawie w 1983 roku.

Warto wiedzieć, że kolekcja Stanisława Lis-Kozłowskiego ma wydzielony w Bibliotece PTPN blok sygnatur od 150.000 z literą „L" na końcu, co pozwala na przejrzenie wszystkich przeniesionych do katalogu komputerowego dzieł przez indeks sygnatur. Prace nad skatalogowaniem komputerowym pozostałych materiałów są dalece zaawansowane.

Księgozbiór po ojcu Stanisława - Władysławie Mieczysławie Kozłowskim - został już w całości opracowany (z wyjątkiem archiwaliów) i jest dostępny w katalogu komputerowym Biblioteki przez indeks sygnatur (bloki sygnatur od 181.001, 182.001, 183.001 i 184.001]. Informacje o obu kolekcjach - przez Internet - są już dostępne szerokim rzeszom hispanistów, historyków, literaturoznawców, badaczy historii i kultury Polonii w Argentynie i Ameryce Łacińskiej. 


\title{
The Argentinian collection in the Library of the Poznań Society of Friends of Arts and Sciences
}

\begin{abstract}
Aвstract. Twenty years ago (in 1989), the Library of the Poznan Society of Friends of Arts and Sciences received a gift from Stanisław Lis-Kozłowski, a Polish exile in Argentina (1907-1995) - a collection of books and materials on Polish matters and related to Poland and the Polish diaspora in Argentina. These materials were complemented with other books published in Argentina and works on the history of Latin America. The donor had been collecting his collection for forty years from the first days of his exile life in Argentina, i.e. from 1948.

Stanisław Lis-Kozłowski was a chemical engineer and a distinguished officer of the Home Army (decorated with the highest Polish, British and French military and state decorations: 24 orders, 16 decorations), minister plenipotentiary of the Polish government in exile (in Paraguay, 1974-1980), activist in many Polish associations in exile, promoter of Polish culture, science and history worldwide (more than 200 bibliographical items), heraldist, collector of Slavic material and a member of many international historical, cultural and heraldic associations and organizations.

The article discusses more interesting items in the collection that covers five thematic groups. From among Polish periodicals published in exile, the most important is a group of 28 titles (including three titles preserved in almost complete runs, i.e. Głos Polski, Nasza Sprawa and Kurier Polski). Other notable collections include over a hundred books published in Argentina in Polish and Spanish (Polish literature, biographies of famous Poles, historical treatises, political and social opinion journalism, and press cuttings related to Poland and Polish matters from Argentinian press from the years 1955-1991.

The collection is available in the reading room of the Library. The state of preservation of the collection is fairly good, whereas some of the works are recorded in the online catalogue of the Library (see the index of the call numbers, starting from the shelf number 150 000, with the letter "L" at the end), and the traditional card catalogue (alphabetical and subject catalogue). The remaining part of the collection is recorded in the inventory books.
\end{abstract}

Key words: Argentinian Polonica (Polish and Poland-related material), Polish diaspora in Argentina, Stanisław Lis-Kozłowski, Władysław Mieczysław Kozłowski. 